\title{
ОЦІНКА ЕФЕКТИВНОСТІ ВИКОРИСТАННЯ РЕСУРСІВ РЕГІОНУ НА ОСНОВІ ОПТИМІЗАЦІЇ ПОДАТКОВОГО НАВАНТАЖЕННЯ
}

\section{О. І. Маслак}

Кременчуцький національний університет імені Михайла Остроградського вул. Першотравнева, 20, м. Кременчук, 39600, Україна. E-mail: oimaslak2017@ gmail.com

Т. М. Одінцова

Чернігівський національний технологічний університет

вул. Шевченка, 95, м. Чернігів, 14035, Україна. E-mail: oditany@ gmail.com

Побудовано традиційну виробничу функцію Кобба-Дугласа Полтавської області з факторами зарплати і капітальних інвестицій. На основі іiі визначено коефіцієнти еластичності впливу цих факторів на формування валового регіонального продукту, які засвідчують про переважання працезатратного, екстенсивного характеру розвитку економічної системи області. Шляхом додаткового введення до виробничої функції податкового навантаження, земельних угідь та витрат на інноваційну діяльність побудовано чотирьох факторну виробничоінституціональна функцію області. На основі визначених економетричних параметрів цієї функції розраховано точку Лаффера 1-го порядку, що відображає податкове навантаження на економіку області на рівні 34,3 \%, при якому продовжується поступове зростання валового регіонального продукту і податкових надходжень. За точки Лаффера 2-го порядку при рівні податкового навантаження 41,3 \% починається скорочення обсягів виробництва та податкових надходжень і формується економічна ситуація переходу економіки до стадії рецесії.

Ключові слова: ефективність, виробнича функція, ресурсний потенціал, фактори виробництва, еластичність, податкове навантаження, точки Лаффера.

\section{ОЦЕНКА ЭФФЕКТИВНОСТИ ИСПОЛЬЗОВАНИЯ РЕСУРСОВ РЕГИОНА НА ОСНОВЕ ОПТИМИЗАЦИИ НАЛОГОВОЙ НАГРУЗКИ}

\section{О. И. Маслак}

Кременчугский национальный университет имени Михаила Остроградского

ул. Первомайская, 20, г. Кременчуг, 39600, Украина. E-mail: oimaslak2017@ gmail.com

\section{Т. М. Одинцова}

Черниговский национальный технологический университет

ул. Шевченка, 95, г. Чернигов, 14035, Украина. E-mail: oditany@gmail.com

Построена традиционная производственная функция Кобба-Дугласа Полтавской области с факторами зарплаты и капитальных инвестиций. На основе ее определенны коэффициенты эластичности влияния этих факторов на формирование валового регионального продукта, которые удостоверяют о преобладании трудозатратног, экстенсивного характера развития экономической системы области. Путем дополнительного введения к производственной функции налоговой нагрузки, земельных угодий и расходов на инновационную деятельность построено четырех факторную производственно-институциональная функцию области. На основе економетрических параметров этой функции рассчитана точка Лаффера 1-го рода, которая отображает налоговую нагрузку на экономику области на уровне 34,3 \%, при которой продолжается постепенный рост валового регионального продукта и налоговых поступлений. При точки Лаффера 2 -го рода и уровне налоговой нагрузки $41,3 \%$ начинается сокращение объемов производства а также налоговых поступлений, формируется экономическая ситуация перехода экономики к стадии рецессии.

Ключовые слова: эффективность, производственная функція, ресурсный потенціал, факторы производства, еластичность, налоговая загрузка, точки Лаффера.

АКТУАЛЬНІСТЬ РОБОТИ. На сучасному етапі розвитку української економіки зростає значимість проблеми забезпечення стійкості регіональних економічних систем і підвищується актуальність теоретико-прикладних методик дослідження стійкого їх розвитку. Дослідження факторів стійкості, які становлять основу функціонування економічних систем разом із системою оподаткування, визначають основний напрям формування динамічного розвитку економічних систем регіонів. Стійкий розвиток регіону забезпечується внаслідок реалізації значного кола факторів. Разом з ресурсами праці, капіталу і земельних ресурсів особливий вплив справляє техніко-технологічний фактор, що комплексно впливає на рівень податкового навантаження, значення якого в залежності від рівня розвитку регіону проявлясться в різних напрямках. Насамперед, це значний фактор форму- вання матеріальної бази регіонального розвитку. Крім того, це важливий інструмент регулювання регіонального розвитку. Нарешті, це дійовий механізм стимулювання розвитку економічних суб’єктів регіону, особливо його провідних галузей і підприємств. 3 цього виходить, що вирішення проблеми економічного зростання регіону залежить від організації ефективного функціонування його ресурсного потенціалу з одночасним нарощуванням власного податкового потенціалу на основі оптимізації податкового навантаження на економіку регіону.

Проблемою дослідження механізму формування ресурсного потенціалу і його впливу на економічне зростання займалися відомі економісти, зокрема: Калінін Н.В. [1], Шумпетер Й. [2], Глазьєв С.Ю. [3]. Автори цих наукових праць прийшли до висновку, що для країн, які розвиваються, необхідною умовою 
підтримання економічного зростання повинен виступати технологічний розвиток, а для країн $з$ високою залежністю від природних ресурсів необхідною умовою зростання $\epsilon$ наявність крупних запасів стратегічних природних ресурсів.

У зв'язку з тим, що кожен регіон функціонує в умовах міжрегіональних виробничо-економічних зв'язків, ці умови характерні і для окремих регіонів. Разом $з$ тим, кожний регіон і фактори його функціонування підлягають тиску з боку існуючої системи оподаткування, без оптимізації якої неможливий соціально-економічний розвиток регіону.

Не зважаючи на досить коротку історію дослідження впливу податкового навантаження на економічне зростання на даний час вже нагромаджено значну кількість результатів досліджень. Головна концепція проблеми податкового навантаження на економіку належить американському економісту Артуру Лафферу [4]. Поглиблення i розширення даної концепції та доведення іï до прикладного вигляду здійснюють Балацкий Е.В. [5, 6, 8], Гусєв А.Б. [7], Какауліна М.О. [9], Ананіашвілі Ю.Ш. і Папава В.Г. [10], Семюелсон Пол і А. Нордгауз Вільям [11]. Цими дослідниками визначена термінологія даної проблематики та розроблені адаптовані модельні криві Лаффера.

Проблемою впливу податків на розвиток економіки займаються також українські економісти Соколовська А. [12], Сушкова О.О. [13], Цимбалюк I.О. [14], Романюта Е. [15]. Разом з тим проблема оптимізації податкового навантаження на економіку регіону з метою іiї позитивного впливу на економічне зростання вимагає поглиблення і розширення 3 метою прикладного іiї застосування.

Метою дослідження $є$ розроблення методології оцінки ефективності ресурсного потенціалу регіону на основі оптимізації податкового навантаження на економіко-виробничу систему регіону.

МАТЕРІАЛ І РЕЗУЛЬТАТИ ДОСЛІДЖЕНЬ. СУчасні неокласичні моделі економічного зростання будуються на основі виробничої функції і базуються на передумовах підвищення зайнятості та взаємної замінюваності факторів виробництва, які уособлюють ресурсний потенціал економічної системи регіону.

Найбільш досконалим інструментарієм, який пов'язує обсяг виробництва з ефективністю використання факторів виробництва нині вважається виробнича функція Кобба-Дуглара, отримана в результаті математичного перетворення виробничої функції $\mathrm{Y}=\mathrm{F}(\mathrm{L}, \mathrm{K})$ в модель, що відображає, якою долею сукупного продукту винагороджується фактор виробництва, що бере участь в його створенні.

Виробнича функція Кобба-Дуглара виглядить наступним чином:

$$
\mathrm{Y}=\mathrm{AK}^{a} \mathrm{~L}^{b}
$$

де Y - обсяг сукупного виробництва, виражений валовим регіональним продуктом (ВРП) ; L - праця, виражена в кількості працюючих або оплаті праці; $\mathrm{K}$ - капітал, як вартість основних засобів або капітальних інвестицій.
Всі показники скориговані на індекс інфляції. Параметр А - це коефіцієнт, що відображає рівень технологічної продуктивності ресурсного потенціалу економічної системи, і у короткотерміновому періоді не змінюється.

Показники $a$ i $b$ - коефіцієнти еластичності обсягу виробництва (Y) за факторами: $a$ - капіталу, $b-$ праці. Це значить, що, якщо кожний із факторів оплачується у відповідності зі своїм граничним продуктом, то $a$ i $b$ показують долю капіталу і праці у сукупному доході.

Якщо $a+b=1$, то відбувається постійна віддача факторів виробництва, при $a+b=>1$ відбувається зростання ефективності факторів виробництва i, відповідно, обсягу виробництва, при $a+b=<1$ ефективність факторів виробництва знижується i, відповідно, відбувається спад виробництва.

Коефіцієнт виробництва показує відносну зміну виробництва, виражену у відсотках, при відносному збільшенні фактора на один відсоток. Якщо еластичність виробництв по капіталу $a$ більший еластичності по праці, то економіка має інтенсивний характер розвитку.

Якщо ж існує нерівність $b>a$, то має місце екстенсивне зростання економіки. Для виявлення механізму формування техніко-технологічного потенціалу регіону та його впливу на формування валового регіонального продукту (ВРП) нами побудована виробнича функція Кобба-Дугласа Полтавської області як одного з провідних регіонів України за техніко-технологічною продуктивністю, де за фактори виробництва взято:

Y - обсяг сукупного виробництва, виражений показником ВРП;

L - праця, виражена оплатою праці;

K - капітал, виражений капітальними інвестиціями.

Y', K', L' - логарифми обсягів виробництва, капітальних інвестицій і оплати праці. Всі показники скориговані на індекс інфляції.

Механізм побудови виробничої функції передбачає логарифмування змінних функції (Y, K, L) та приведення функції в лінійний вигляд за допомого функції Лінейн в Ексель (табл. 1).

Розрахунки привели виробничу функцію Полтавської області до вигляду:

$$
\mathrm{Y}=1,964 \mathrm{~K}^{0,026} \mathrm{~L}^{1,146} .
$$

Формула виробничої функції області засвідчує, по-перше, про високу продуктивність технікотехнологічного ресурсу економічної системи (А = 1964). В той же час коефіцієнти еластичності фактору капіталу $(\mathrm{a}=0,026)$ і праці $(\mathrm{b}=1,146)$ засвідчують за те, що зростання обсягів реалізації області відбувається екстенсивним методом за рахунок фактору праці i раніше створеного технікотехнологічного потенціалу. Виробництво стримується недостатніми інвестиціями на підтримання техніко-технологічного потенціалу. Разом 3 тим економічна система області ще утримується від рецесії виробництва. 
Таблиця 1 - Розрахунок формули виробничої функції Полтавської області (млрд. грн.)

\begin{tabular}{|l|c|c|c|c|c|c|c|}
\hline Роки & $\mathrm{Y}$ & $\mathrm{K}$ & $\mathrm{L}$ & $\mathrm{Y}^{\prime}$ & $\mathrm{K}^{\prime}$ & $\mathrm{L}^{\prime}$ & Y poзрах. \\
\hline 2007 & 19,1 & 7,3 & 7,3 & 2,950 & 1,988 & 1,988 & 20 \\
\hline 2008 & 23,4 & 5,4 & 9 & 3,153 & 1,686 & 2,197 & 25 \\
\hline 2009 & 26,7 & 6,8 & 9,9 & 3,285 & 1,917 & 2,293 & 29 \\
\hline 2010 & 38,9 & 7 & 10,6 & 3,661 & 1,946 & 2,361 & 31 \\
\hline 2011 & 45,7 & 6,9 & 13,9 & 3,822 & 1,932 & 2,632 & 42 \\
\hline 2012 & 52,5 & 9,5 & 16,9 & 3,961 & 2,251 & 2,827 & 53 \\
\hline 2013 & 56,1 & 9,1 & 18,5 & 4,027 & 2,208 & 2,918 & 59 \\
\hline 2014 & 60,2 & 7,6 & 19,7 & 4,098 & 2,028 & 2,981 & 63 \\
\hline 2015 & 69 & 6 & 17,2 & 4,234 & 1,792 & 2,845 & 54 \\
\hline 2016 & 99,3 & 13 & 24,5 & 4,598 & 2,565 & 3,199 & 82 \\
\hline
\end{tabular}

Джерело: Розрахунки автора з використанням Статистичного збірника «Регіони України 2017 р.

Стабільне функціонування виробництва на основі вже створеного високотехнологічного потенціалу регіону відбувається під впливом механізму оподаткування його економічної системи. У зв'язку з цим пріоритетним напрямом податкової політики регіону є формування стійкого податкового потенціалу за рахунок розширення джерел податкових надходжень, збалансування доходів і витрат виробництва. Ефективна податкова система виступає важливим фактором динамічного розвитку економіки регіону, стимулюючи економічне зростання і оптимальні фінансові потреби. Сучасна проблема побудови оптимальної податкової системи вирішується шляхом відшукування лафферових точок [4] стосовно до показників загального податкового навантаження на економічну систему регіону. При цьому сама величина узгодження двох лафферових точок виступає в якості головного критерію і індикатора ефективності регіональної системи.

Фіскальне регулювання економіки має три мети або принципи:

Перша мета - забезпечити зняття протиріччя між інтересами виробників і бюджетом;

Друга мета - збалансування номінального податкового навантаження на правій дузі виробничої кривої Лаффера за таких умов, щоб величина номінального податкового навантаження не була більшою значення точки Лаффера 2-го порядку, після якого, як правило починається спад і виробництва i податкових надходжень (рис. 1).

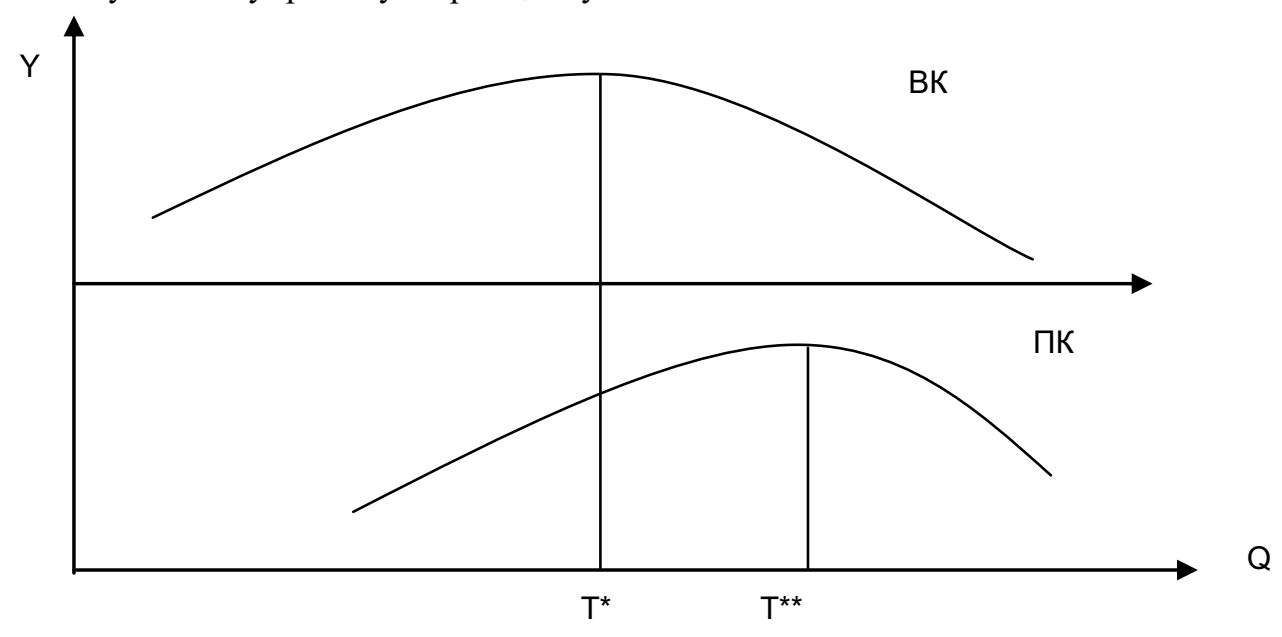

Рисунок 1 - Положення точок Лаффера на виробничій і податковій кривих:

ВК виробнича крива; ПК - податкова крива; $\mathrm{T}^{*}, \mathrm{~T}^{* *}$ - точки Лаффера 1-го і 2-го порядків

Джерело: побудовано автором з використанням $[4,5,6]$

Третя мета - формування податкової системи, в якій забезпечується мінімум заборгованості по податках. Відзначені принципи розробки фіскальної політики дозволяють широко використовувати фіскальні індикатори при здійсненні прикладних прогнозно-аналітичних розрахунків напрямів стабіль- ного розвитку економіки регіону. Ці індикатори можуть також застосовуватися для здійснення прикладних прогнозних розрахунків формування обсягів регіонального виробництва та податкових надходжень до регіонального і національного бюджетів.

В роботах Є.В. Балацького і інших дослідників 
$[5,6,7,8,9]$ були розроблені загальна методологія та інструментарій проведення прогнозноаналітичних розрахунків впливу податків на економічне зростання і формування бюджету країни, а також було проведено аналіз ефективності фіскальної політики держави. В даний час методологія моделювання виробничо-фіскальних ефектів знайшли своє більш повне відображення у поділі впливу податків на дві складові. Перша 3 них пов'язана 3 вивченням формування виробничої кривої ВК, друга - податкової кривої ПК (рис. 1). Виробнича крива досягає локального максимуму в точці T* і відображає точку Лаффера 1-го порядку. Податкова крива досягає свого максимуму в точці $\mathrm{T}^{* *} \mathrm{i}$ отримала назву точки Лаффера 2-го порядку.

3 економічної точки зору точка Лаффера 1-го порядку означає податкове навантаження, при якому відбувається зростання обсягів виробництва (Y) i податкових надходжень (Q), тобто економіка ще не переходить до стадії рецесії. Точка Лаффера 2-го порядку вказує величину податкового навантаження, за межами якого одночасне збільшення обсягів виробництва і податкових надходжень стає неможливим, а економіка входить у стадію рецесії. Ідентефікація точок Лаффера 1-го і 2-го порядку ї їх співставлення 3 фактичним обсягом виробництва i податковим навантаженням дозволяє оцінити ефективність кількісної побудови податкової системи і визначити напрями іiі оптимізації. В цьому якраз i полягає основна ідея використання розширеної концепції кривої Лаффера.

Основу податкового клімату складає виробничоінституціональна функція (ВІФ), що є узагальненням традиційного апарату виробничої функції стосовно до макрорівня. Різниця полягає у тому, що у звичайній виробничій функції в якості ендогенного показника застосовується обсяг виробництва, зокрема ВНП або ВРП, праця, і капітал, в той час як у виробничо-інституціональній функції (ВІФ) набір макроекономічних факторів доповнюється змінною, яка характеризує інституціональне середовище середнє податкове навантаження, як доля податків у ВВП. Враховуючи, що крім технологічного або ресурсного аспекту економічного зростання в моделі враховується ще й податковий клімат, то відпові-

дно й традиційна ВФ трансформується у ВІФ. Стосовно до визначення функціональної залежності ВІФ має наступний вигляд:

$$
\mathrm{Y}=\gamma \mathrm{DL}{ }^{(a+b T) T} \mathrm{~K}^{(c+d T) T}
$$

де $\mathrm{Y}$ - обсяг виробництва (ВВП, ВРП) країни; К капітал (капітальні інвестиції); L - праця (оплата праці найнятих працівників ); Т - податкове навантаження, обраховане як доля податкових надходжень Т у ВВП або ВРП, (Т = Q/ВВП); Д - трендовий оператор; $\gamma$, а, в ,с, д - параметри, оцінювані статистично на основі ретроспективних динамічних рядів. Всі фактори беруться за ряд років, як правило, не менше десяти років.

Особливості функції (2) полягає в тому, що суспільний продукт країни або регіону залежить від праці, капіталу і податкового тиску, при чому вплив праці і капіталу на економічне зростання само залежить від податкового клімату. Крім того, еластичність праці і капіталу є квадратичними функціями податкового навантаження, що автоматично зумовлює специфічність всього аналізу. Функція (2) задає виробничу криву, тобто залежність між виробництвом і податковим навантаженням. Тоді податкова крива, тобто залежність між обсягом податків і відносним податковим навантаженням виражається наступною функцією:

$$
\mathrm{Q}=\gamma \mathrm{TDL}{ }^{(a+b T) T^{2}} \mathrm{~K}^{(c+d) T^{2}}
$$

де Q - обсяг податкових надходжень.

Стержнева ідея податкового аналізу на основі ВІФ (2) і (3) є визначення взаємного розташування точок Лаффера 1-го і 2-го порядку та рівнів величин податкового навантаження. Розгляд трьох фіскальних індикаторів дозволяє відобразити досить повну картину податкового клімату і визначити іï роль у формуванні динаміки економічного зростання. Після відповідних перетворень точки Лаффера 1-го і 2го порядків стає можливим вираховувати наступним чином:

$$
\mathrm{T}^{*}=-\frac{1}{2} \frac{a \ln L+c \ln K}{b \ln L+d \ln K}
$$

$$
\mathrm{T}^{* *}=\frac{ \pm}{-} \frac{\sqrt{(a L+c K) 2-3(b L+d K) B}-(a L+c K)}{3(b L+d K)}
$$

Разом 3 важливістю кривої Лаффера в проблемі стабілізації розвитку економіки та розширення виробничої функції до виробничо-інституціональної функції шляхом введення до неї податкового навантаження окремі дослідники зауважують, що тільки введення оптимальної середньої податкової ставки не може ініціювати перехід до рівноваги, що відповідає повній зайнятості, або забезпечити максимальну мобілізацію податкових надходжень до бюджету [11]. В умовах лафферо-кейнсіанського син- тезу суттєву роль у підвищенні економічної активності і досягненні повної зайнятості, разом із режимом оподаткування, відіграє сукупний попит і сукупна пропозиція.

Відповідно $з$ макроекономічною теорією ВНП має два розрахунки, що відображають рівновагу доходів і рівновагу витрат в економіці [11]. Схематично рівновага в економіці відображається наступним чином: 
ВНП як потік витрат $=\mathrm{C}+\mathrm{I}+\mathrm{Y}+\mathrm{X}$,

де C - споживання, I - інвестиції, У - урядові витрати, витрати на чистий експорт;

$$
\text { ВНП як потік доходів }=3+\mathrm{B}+\mathrm{P}+\Pi \text {, }
$$

де 3 - заробітна плата, В - відсотки від депозитів, Р - рента, П - прибуток підприємств.

Наведені макроекономічні рівності підводять до висновку, що для повного відображення економічних процесів, які відбуваються під впливом оподаткування, необхідне в розрахунки ВІФ по можливості ввести всі наявні фактори макроекономічної рівноваги. Переслідуючи ці вимоги окремі дослідники до розрахунків ВІФ додатково ввели фактор земельних ресурсів [9]. Нами ВІФ розширена додатковим введенням в розрахунки крім земельних угідь ще фактора інноваційного потенціалу [16]. Після цього ВІФ набрала вигляду:

$$
\mathrm{Y}=\gamma \mathrm{DL}{ }^{(a+b T) T} \mathrm{~K}^{(c+d T) T} \mathrm{M}^{(m+n T) T} \mathrm{I}{ }^{(i+k T) T} .
$$

$$
\mathrm{Q}=\gamma \mathrm{TDL}{ }^{(a+b T) T^{2}} \mathrm{~K}{ }^{(c+d) T^{2}} \mathrm{M}^{(m+n T) T^{2}} \mathrm{I}^{(i+k T) T^{2}}
$$

На основі формул (8) і (9) формули вирахування точок Лаффера 1-го і 2-го порядку набирають вигляду:

$$
\begin{gathered}
\mathrm{T}^{*}=-\frac{1}{2} \frac{a \ln L+c \ln K+\mathrm{m} \ln M+\ln I}{b \ln L+d \ln K+n \ln M+\ln K} \\
\mathrm{~T}^{* *}= \pm \frac{\sqrt{(a L+c K+m M) 2-3(b L+d K+n M+\ln I) B}-(a L+c K+m M+\ln I)}{3(b L+d K+n M+\ln K)},
\end{gathered}
$$

де, L - обсяг праці, виражений заробітною платою; $\mathrm{K}$ - обсяг капітальних інвестицій; M - обсяг земельних ресурсів; I - витрати на інноваційну діяльність.

Обсяги факторів виробництва у вартісній оцінці коректуються на річні індекси інфляції. 3 наведених формул видно, що дана виробнича функція відображає залежність між виробництвом продукції і значеннями факторів праці, капіталу, землі й інновацій, що більш повніше відображає потік доходів і витрат економічного потенціалу регіону. Тобто, за допомогою економетричної формули функції можна прогнозувати обсяги виробництва при різних значеннях факторів виробництва і ставок оподаткування по регіонах країни. Побудову розширеної ВІФ нами апробовано на статистичних показниках функціонування Полтавської області (табл. 2, 3).

Таблиця 2 - Статистичні показники функціонування Полтавської області (млн. грн)

\begin{tabular}{|c|c|c|c|c|c|c|c|}
\hline Роки & $\begin{array}{c}\text { ВРП (Y) } \\
\text { з ураху- } \\
\text { ванням } \\
\text { інфляції }\end{array}$ & $\begin{array}{c}\text { Зарабітна } \\
\text { плата (L) } \\
\text { з ураху- } \\
\text { ванням } \\
\text { інфляції }\end{array}$ & $\begin{array}{c}\text { Капитальні } \\
\text { інвестиії (K) } \\
\text { з ураху- } \\
\text { ванням ін- } \\
\text { фляції }\end{array}$ & $\begin{array}{c}\text { Площа } \\
\text { сільгосп. } \\
\text { земель } \\
(\mathrm{M})\end{array}$ & $\begin{array}{c}\text { Інноваційні } \\
\text { витрати } \\
\text { (I) 3 ураху- } \\
\text { ванням інф- } \\
\text { ляції }\end{array}$ & $\begin{array}{c}\text { Податкові } \\
\text { платежі } \\
\text { (Q) 3 ура- } \\
\text { хуван-ням } \\
\text { інфляції }\end{array}$ & $\begin{array}{c}\text { Фактичне } \\
\text { податкове } \\
\text { наванта- } \\
\text { ження (Т з } \\
\text { урахуванням } \\
\text { інфляції) }\end{array}$ \\
\hline 2007 & 19128 & 7298 & 7298 & 1932 & 28 & 2907 & 0,152 \\
\hline 2008 & 23365 & 8969 & 5433 & 1907 & 31 & 3645 & 0,156 \\
\hline 2008 & 26734 & 9877 & 6844 & 1903 & 37 & 7058 & 0,264 \\
\hline 2010 & 38920 & 10636 & 4557 & 1896 & 40 & 10512 & 0,269 \\
\hline 2011 & 45715 & 13905 & 6875 & 1889 & 49 & 15509 & 0,339 \\
\hline 2012 & 52486 & 16879 & 8979 & 1886 & 54 & 17600 & 0,335 \\
\hline 2013 & 56054 & 18517 & 8143 & 1874 & 67 & 18161 & 0,324 \\
\hline 2014 & 60251 & 17676 & 8386 & 1872 & 65 & 12593 & 0,209 \\
\hline 2015 & 69019 & 17195 & 7032 & 1841 & 65 & 16674 & 0,243 \\
\hline 2016 & 99293 & 24515 & 13036 & 1842 & 51 & 21914 & 0,22 \\
\hline
\end{tabular}

Джерело: Розрахунки автора з використанням Статистичного збірника «Регіони України 2017 р. 
Таблиця 3 - Параметри економетричної моделі Полтавської області

\begin{tabular}{|c|c|c|c|c|c|c|c|c|c|}
\hline $\mathrm{t}$ & $\mathrm{nY}$ & $\mathrm{T}^{*} \ln \mathrm{L}$ & $\mathrm{T} 2 * \ln \mathrm{L}$ & $\mathrm{T} * \ln \mathrm{K}$ & $\mathrm{T}^{2} * \ln \mathrm{K}$ & $\mathrm{T} * \ln \mathrm{M}$ & $\mathrm{T} 2 * \ln \mathrm{M}$ & $\mathrm{T} * \ln \mathrm{I}$ & $\mathrm{T} 2 * \ln \mathrm{I}$ \\
\hline 1 & 9,8589 & 1,2476 & 0,1410 & 1,2222 & 0,1650 & 1,3317 & 0,2344 & 0,5065 & 0,1032 \\
\hline 2 & 10,0590 & 1,4198 & 0,2215 & 1,3416 & 0,2093 & 1,3294 & 0,2340 & 0,5357 & 0,1064 \\
\hline 3 & 10,1937 & 2,4283 & 0,6411 & 2,3314 & 0,6155 & 1,9935 & 0,5263 & 0,9533 & 0,2517 \\
\hline 4 & 10,5693 & 2,4942 & 0,6709 & 2,2662 & 0,6096 & 2,0303 & 0,5461 & 0,9923 & 0,2669 \\
\hline 5 & 10,7302 & 3,2341 & 1,0963 & 2,9953 & 1,0154 & 2,5573 & 0,8669 & 1,3193 & 0,4473 \\
\hline 6 & 10,8683 & 3,2608 & 1,0924 & 3,0494 & 1,0215 & 2,5266 & 0,8464 & 1,3363 & 0,4477 \\
\hline 7 & 10,9341 & 3,1838 & 1,0315 & 2,9176 & 0,9453 & 2,4416 & 0,7911 & 1,3623 & 0,4414 \\
\hline 8 & 11,0063 & 2,0440 & 0,4272 & 1,8882 & 0,3946 & 1,5748 & 0,3291 & 0,8724 & 0,1823 \\
\hline 9 & 11,1421 & 2,3698 & 0,5759 & 2,1525 & 0,5231 & 1,8269 & 0,4439 & 1,0144 & 0,2465 \\
\hline 10 & 11,5058 & 2,2235 & 0,4892 & 2,0846 & 0,4586 & 1,6541 & 0,3639 & 1,3617 & 0,1920 \\
\hline & $-23,20$ & 81,61 & $-15,34$ & $-56,79$ & 13,14 & $-26,32$ & 23,34 & $-379,7$ & 86,48 \\
\hline Коефіцієнти & B & $\mathrm{a}$ & $\mathrm{b}$ & $\mathrm{c}$ & $\mathrm{d}$ & $\mathrm{m}$ & $\mathrm{n}$ & $\mathrm{i}$ & $\mathrm{k}$ \\
\hline Значення & 86,48 & 23,34 & $-26,32$ & 13,14 & $-56,79$ & $-15,34$ & $81,61,33$ & $-2,58$ & $-23,20$ \\
\hline $\begin{array}{c}\text { Статистичні пара- } \\
\text { метри }\end{array}$ & \multicolumn{9}{|c|}{$\mathrm{R}^{2}=0,985 ; \mathrm{F}=46,35 ; \mathrm{N}=10$} \\
\hline
\end{tabular}

Джерело: Розроблено автором за результати розрахунків у табл. 2.

На основі розрахованих економетричних параметрів функціонування економічної системи Полтавської області $B, a, b, c, d, m, n, i, k$ за формулами (9) i (10) розраховуються точки Лаффера 1-го (Т*) і 2-го ( $\left.{ }^{* *}\right)$ порядків:

$$
\begin{aligned}
& \mathrm{L}=10,11 ; \mathrm{K}=9,48 ; \mathrm{M}=7,52 ; \mathrm{I}=6,19 . \\
& \mathrm{T}^{*}=23,6+124,6-427,1-16 / 2(-266,1- \\
& -538,4+613,7-143,6)=229,2 / 668,8=\mathbf{0 , 3 4 3} ; \\
& \mathrm{T}^{* *}=(\sqrt{5} 2533-86757)+229,2=414,2 /-1003,2
\end{aligned}
$$$$
=\mathbf{0 , 4 1 3} \text {. }
$$

За допомогою економетричних показників $B, a$, $b, c, d, m, n, i, k$ та точок Лаффера 1-го і 2-го порядків появляється можливість розраховувати обсяги виробництва (Y) та надходження податкових платежів (Q) відповідно до рівня податкового навантаження на економіку області за формулами:

$$
\mathrm{Y}=(\mathrm{a}+\mathrm{bT}) \mathrm{TL}+(\mathrm{c}+\mathrm{dT}) \mathrm{TK}+(\mathrm{m}+\mathrm{nT}) \mathrm{TM}+\mathrm{B} .
$$

$$
\mathrm{Q}=(\mathrm{a}+\mathrm{bT}) \mathrm{T}^{2} \mathrm{~L}+(\mathrm{c}+\mathrm{dT}) \mathrm{T}^{2} \mathrm{~K}+(\mathrm{m}+\mathrm{nT}) \mathrm{T}^{2} \mathrm{M}+\mathrm{BT}
$$

Позначивши розрахункові обсяги виробництва i податкових надходжень за умовами точки Лаффера 1-го порядку $\mathrm{Y}^{*} \mathrm{i} \mathrm{Q}^{*}$, відповідно 2-го порядку - $\mathrm{Y}^{* *}$ $\mathrm{i} \mathrm{Q}^{* *}$, в результаті розрахунків отримаємо:

$$
\begin{gathered}
\mathrm{Y}^{*}=120279-28348+7999-184+86=99881 ;(14) \\
\mathrm{Y}^{* *}=126255-55508+13967-256+86=84544 ;(15) \\
\mathrm{Q}^{*}=41255-9719+2742-68+30=34245 ; \quad(16) \\
\mathrm{Q}^{* *}=51569-22848+5749-105+36=35801 . \quad(17)
\end{gathered}
$$

Розрахунки показують, що нарощування обсягів виробництва і податкових надходжень за рахунок сформованого роками ресурсного потенціалу в Полтавській області можливий в межах податкового навантаження від 34,3 до 41,3 \%. Вже за податкового навантаження 41,3 \% починається скорочення обсягів виробництва, що провокує скорочення обсягів заробітної праці, капітальних інвестицій, витрат на інноваційну діяльність та інші процеси інфляційного характеру. Тобто починається рецесія виробництва.

Побудована економетрична модель Полтавської області за ВІФ (табл. 3) відобразила досить важливу властивість макроекономічного розвитку Полтавсь- кої області. Виявлена форма факторних зв'язків ресурсного потенціалу області відобразила переплетіння технологічного і фіскального факторів економічного зростання. Економетричний показник $B$, який у виробничо-інституціональній функції відображає продуктивність техніко-технологічного ресурсу економічної системи, за рівня 86,48 у Полтавській області значно перевищує показники інших індустріально розвинутих областей України. Зокрема у Львівській області він становить 73,41, Одеській - 55,27, Харківській - 21,23, Дніпропетровській $-12,6[16]$.

Разом 3 тим сформований роками технікотехнологічний потенціал області, що характеризується оптимальною пропорцією промислового i аграрного сегментів економіки, сприяє стабільному нарощуванню обсягу виробництва i податкових надходжень. В той же час розрахунки засвідчують, що для стабільного поступового розвитку області необхідно постійно дотримуватися оптимального податкового навантаження на галузі економіки і в цілому на економічну систему, що сприятиме підвищенню соціально-економічного стану області. Разом $з$ тим для стабільного зростання обласного 
виробництва необхідно пріоритетну увагу надавати зростанню капітальних інвестицій для розвитку провідних підприємств і галузей області.

ВИСНОВКИ. Побудова традиційної виробничої функції Кобба-Дугласа Полтавської області дало можливість розрахувати коефіцієнти еластичності впливу факторів заробітної плати і капітальних інвестицій на формування обсягів валового регіонального продукту. Значне перевищення коефіцієнта еластичності фактора заробітної плати над коефіцієнтом капітальних інвестицій засвідчує на те, що економічна система області через недостатність витрат на оновлення техніко-технологічного потенціалу економіки поступово переходить на працезатратний, екстенсивний метод розвитку. Шляхом побудови розширеної виробничо-інстиціональної функції розраховано економетричні параметри функціонування економіки області, за допомого яких розраховано точки Лаффера 1-го і 2-го порядків, що дали можливість виявити межі податкового навантаження, за яких відбувається або зростання обсягів валового регіонального продукту і податкових надходжень, або економіка входить у стадію рецесії. Доведено, що у короткочасному періоді податкове навантаження на економічну систему області не повинне перевищувати рівня 41,3\%.

Запропонована у статті виробничоінституціональна функція зі факторами, що відображають ресурсний потенціал праці у вигляді заробітної плати, капітал у вигляді капітальних інвестицій, інноваційний потенціал і земельні ресурси може застосуватися у відповідних модифікаціях для моделювання розвитку в цілому економіки, галузей економіки, об’єднань підприємств, корпорацій i окремих підприємств.

\section{ЛІТЕРАТУРА}

1. Калинин Н. В. Ресурсный потенциал в оценке экономического роста региона. Успехи современного естествознания. 2004. № 6. С. 59 - 60 .

2. Шумпетер Йозеф. Теория экономического развитя: монографія. М. : Директмедиа Паблишинг, 2008. $401 \mathrm{c}$.

3. Глазьев С. Ю. Новый технологический уклад в соаременной мировой экономике. Международная экономика. 2010. № 5. С. 5 -27.
4. Laffer A. B. The Laffer Curve Past, Present, and Futur. Heritage foundation. 2004. № 1765. Р. 1 - 16.

5. Балацкий Е. В. Оценка влияния фискальных инструментов на экономический рост. Проблемь прогнозирования. 2004. № 4. С. $124-135$.

6. Балацкий Е. В. Анализ влияния налоговой нагрузки на экономический рост с помощью производственно-институциональных функцій. Проблемь прогнозирования. 2003. № 2. С. $88-105$.

7. Гусев А. Б. Налоги и экономический рост: теории и эмпирические оценки : учеб. пособ. М. : Экономика и право, 2003. 139 с.

8. Балацкий Е. В. Налогово-бюджетная политика и экономический рост. Общество и экономика. 2011. № 4 - 5. С. 136-144.

9. Какаулина М. О., Цепелев О. А. Моделирование влияния налоговой нагрузки на экономический рост с учетом ресурсного потенциала : учеб. пособ. Владивосток : Дальнаука, 2014. 428 с.

10. Ананиашвили Ю. Ш., Папава В. Г. Налоги и макроэкономическое равновесие: лафферокейнсианський синтез : учебн. пособ. Стокгольм : CA\&CC Press, 2010. 142 c.

11. Семюелсон Пол А., Нордгауз Д. Вільям Макроэкономика : учебн. пособ.. Пер. 3 англ. К. : «Основи», 1995. 544 с.

12. Соколовська А. Теоретичні засади визначення податкового навантаження та рівня оподаткування економіки. Економіка України. 2006. № 7. C. 7-13.

13. Сушкова Е. Е. Анализ подходов к оценке уровня налоговой загрузки как фактора экономического развития региона. Экономика Крыма. 2008. № 25. C. $25-29$.

14. Цимбалюк. І. О., Міщанчук О. О. Особливості визначення податкового навантаження на рівні держави та регіону. Вісник Хмельницького національного університету. 2014. № 3. Т. 2. С. 101 - 106.

15. Романюта. Е. Моніторинг рівня податкового навантаження в Україні та країнах СС. Світ науки. 2017. № 2 (151). С. 128 - 138 .

16. Одінцова. Т. М. Вплив податкового навантаження на економічний розвиток регіонів: кластерний підхід. Облік і фінанси. 2018. № 1 (79). С. $114-$ 123.

\section{ASSESSMENT OF THE EFFICIENCY OF THE USE OF THE REGIONAL RESOURCES ON THE BASIS OF THE TAX OPTIMIZATION}

\section{O. Maslak}

Kremenchuk Mykhailo Ostrohradskyi National University

vul. Pervomayskaya, 20, Kremenchuk, 39600, Ukraine. E-mail: oimaslak2017@gmail.com

\section{T. Odintsova}

Chernihiv National University of Technology

vul. Shevchenko, 95, Chernigov, 14035, Ukraine. E-mail: oditany@gmail.com

Purpose. The traditional Cobb-Douglas production function of the Poltava region built together with salary and capital investmentfactors. On its basis the coefficients of the elasticity of the influence of these factors on the formation of the gross regional product were determined. Methodology. By additional introduction of the tax burden to the production function, land and the cost of innovation, a four-factorial production and institutional function of the region was built. Results. Based on certain econometric parameters (which were mentioned before) of this function, the Laffer point of the 1st order is calculated, which reflects the tax burden on the regional economy at level of $34.3 \%$, where the gross regional product and tax revenues continue to grow. At Laffer point of the 2 nd order with a tax burden level of $41.3 \%$, production volumes and tax revenues are being reduced and the situation of the economy 
transition to the recession stage is being formed. Originality. A significant excess of the coefficient of elasticity of the wage factor over the capital investment ratio indicates that the economic system of the region is gradually moving to a labor-intensive, extensive development method due to insufficient expenditures on updating the technical and technological potential of the economy. Practical value. The production-institutional function proposed in the article with factors that reflect the resource potential of labor in the form of wages, capital in the form of capital investments, innovation potential and land resources, can be used in appropriate modifications for modelling the development of the whole economy, industries, associations, enterprises, corporations and individual enterprises. The econometric model of the Poltava region, which was built, reflects a very important feature of the macroeconomic development of the Poltava region. The revealed form of factor relations of the resource potential of the region shows the interweaving of technological and fiscal factors of economic growth. The economic indicator B, which in the production-institutional function reflects the productivity of the technical and technological resource of the economic system, at the level of 86,48 in the Poltava region which significantly exceeds the indicators of other industrially developed regions of Ukraine. References 16, figures1, tables 3.

Key words: efficiency, production function, resource potential, production factors, tax burden, Laffer points.

\section{REFERENCES}

1. Kalinin, N. V. (2004), "Resursnyiy potentsial v otsenke ekonomicheskogo rosta regiona» [Resource potential in assessing the economic growth of the region], Uspekhi sovremennogo yestestvoznaniya, no.6, pp. 59-60.

2. Schumpeter, Joseph (2008), «Teoriya ekonomicheskogo razvitiya» [The Theory of Economic Development: monograph], Directmedia Publishing, Moscow, 401p.

3. Glaz'yev, S. Yu. (2010), «Novyiy tehnologicheskiy uklad v sovremennoy mirovoy ekonomike» [New technological structure in the modern world economy], Mezhdunarodnaya ekonomika, no.5, pp. 5-27.

4. Laffer, A. B. (2004), The Laffer Curve Past, Present, and Future, Heritage foundation, no. 1765, pp. 116.

5. Balatskiy, Ye. V. (2004), «Otsenka vliyaniya fiskalnyih instrumentov na ekonomicheskiy rost» [Assessing the impact of fiscal instruments on economic growth], Problemy prognozirovaniya, no.4, pp. 124135 .

6. Balatskiy, Ye. V. (2003), «Analiz vliyaniya nalogovoy nagruzki na ekonomicheskiy rost $s$ pomoschyu proizvodstvenno-institutsionalnyih funktsiy» [Analysis of the impact of tax burden on economic growth with the help of production and institutional functions], Problemy prognozirovaniya, no.2, pp. 88105.

7. Gusyev, A. B. «Nalogi i ekonomicheskij rost: teorii i empiricheskie ocenki : ucheb. Posob» [Taxes and economic growth: theories and empirical estimates: studies. allowance]. M.: Economy and right, 2003. 139 p.

8. Balatskiy, Ye. V. (2011), «Nalogovo-byudzhetnaya politika i ekonomicheskiy rost» [Fiscal policy and economic growth], Obshchestvo i ekonomika, no.4-5, pp. 136-144.

9. Какаulinya, М. О., Tsepelev, О. А. «Modelirovanie vliyaniya nalogovoj nagruzki na ekonomicheskij rost s uchetom resursnogo potenciala : ucheb. posob. Vladivostok» [Modeling the effect of tax burden on economic growth, taking into account the resource potential: studies. benefit Vladivostok], Dal'nauka, 2014. $428 \mathrm{p}$.

10. Anyaniachvili, U. Sh., Papava, V. G. «Nalogi $i$ makroekonomicheskoe ravnovesie: laffero-kejnsianskij sintez : uchebn. posob. Stokgolm» [Taxes and macroeconomic equilibrium: Laffero-Keynesian synthesis: textbook. benefit Stockholm], CA\&CC Press, 2010. 142 p.

11. Samuelson, P. A., Nordhaus, W. D. «Makroekonomika: uchebn. posob. Per. $\mathrm{z}$ angl.» [Macroeconomics: studies. benefit. Trans. s eng.] K.: Bases, 1995. $554 \mathrm{p}$.

12. Sokolovska, A. (2006), "Teoretychni zasady vyznachennia podatkovoho navantazhennia ta rivnia opodatkuvannia ekonomiky» [Theoretical principles of determining the tax burden and the level of taxation of the economy], Ekonomika Ukrainy, no.7, pp. 7-13.

13. Sushkova, Ye. Ye. (2008), "Analiz podhodov $k$ otsenke urovnya nalogovoy zagruzki kak faktora ekonomicheskogo razvitiya regiona» [Analysis of approaches to assessing the level of tax load as a factor of the region economic development], Ekonomika Kryma, no. 25 , pp. $25-29$.

14. Tsymbaliuk, I. O., Mishchanchuk, O. O. (2014), «Osoblyvosti vyznachennia podatkovoho navantazhennia na rivni derzhavy ta rehionu» [Features of definitions and directions optimization of tax loading], Transactions of Kremenchuk Mykhailo Ostrohradskyi National University, no.3, pp. 101-106.

15. Romanyuta, E. (2017), «Monitorynh rivnia podatkovoho navantazhennia $v$ Ukraini ta krainakh $Y e S$ » [The monitoring of the tax burden in the Ukraine and the countries EU], Svit nauky, no.2(151), pp. 128138.

16. Odintsova, T. M. (2018), «Vplyv podatkovoho navantazhennia na ekonomichnyi rozvytok rehioniv: klasternyi pidkhid» [Influence of tax burden on economic development of regions: cluster approach], Oblik $i$ finansy, no.1(79), pp. 114-123. 